\title{
Differences in Language Policies of Chinese-inhabited Southeast Asian Countries
}

\author{
Kristína Kironská \\ Institute of China and Asia-Pacific Studies \\ National Sun Yat-sen University
}

\begin{abstract}
Language is a tool that governments use to create national identity. Language policies are not static and with the impact of several factors can shift over time. With the influx of new immigrants, both the ethnic and linguistic structures of countries change, as had been the case with the Chinese immigrants who arrived in Southeast Asia in two big waves, in the 15th/16th and later in the 19th/20th century and made it their new home. Today, some 30 million overseas Chinese live in Southeast Asia, most prominently in Malaysia, the Philippines, Singapore, Indonesia, Thailand, Myanmar, and in Vietnam. Some of these countries pursue monolingual policies, while others have opted for multilingualism. This article explains the differences in regard of the presence or absence of the Chinese language in the language policies of Southeast Asian countries with a substantial Chinese minority. First of all, authoritarian regimes are generally associated with less minority language recognition, and thus the Chinese language is less likely to be included in the official language apparatus in a dictatorship. Second, if the Chinese minority is included in the government, it is more likely that the Chinese language be either one of the official languages, or one of the languages of instruction, or both. And third, the bigger and more coherent the Chinese minority, the bigger the chance of the Chinese language being part of the national language policy. The author has identified three variables that influence the Chinese language participation in the language policy of a country, namely the country's regime type, the size and cohesion of the Chinese minority living in that country, and the Chinese minority's access to the national government. The approach used in this article is both descriptive and analytical, and offers a comparative review of the language policy structures of various countries throughout Southeast Asia in regard of the Chinese language.
\end{abstract}

KEY WORDS: Southeast Asia, language policy, the Chinese language

\section{ABOUT THE AUTHOR}

Kristina Kironska was born in Slovakia in 1984 to a multilingual family. She studied International Relations in Slovakia and Portugal. In 2008, she moved to Taiwan, where she completed a Master degree in China and Asia-Pacific Studies. Currently, she is pursuing her PhD degree at the College of Social Sciences of the National Sun Yat-sen University in Kaohsiung, Taiwan. She can be reached at: k.kironska@gmail.com

\section{INTRODUCTION}

Today, over 30 million Chinese (excluding the offspring of mixed ethnicity) live in Southeast Asia, (see Table 1). The Chinese population makes up around $5 \%$ of the Southeast Asian population, but controls around $60 \%$ of local Southeast Asian industry, trade, and commerce (McVey, 1992) The term Chinese refers strictly to ethnic origin (and throughout this paper is considered a synonym with overseas Chinese and ethnic Chinese), not nationality. 
TABLE 1: AMOUNT OF ETHNIC CHINESE IN SOUTHEAST ASIA (2012)

\begin{tabular}{|l|r|}
\hline Country & $\begin{array}{l}\text { Chinese } \\
\text { population }\end{array}$ \\
\hline Indonesia & 8120000 \\
\hline Thailand & 7510000 \\
\hline Malaysia & 6780000 \\
\hline Singapore & 2830000 \\
\hline Philippines & 1410000 \\
\hline Myanmar & 1060000 \\
\hline Vietnam & 1000000 \\
\hline Laos & 150000 \\
\hline Cambodia & 120000 \\
\hline Brunei & 40000 \\
\hline
\end{tabular}

Source: Statistics: Overseas Chinese Population, Overseas Community Affairs Council R.O.C. (modified by the author). Retrieved on 25 January 2014 from

http://www.ocac.gov.tw/english/public/public.asp?selno=8889\&no=8889\&level=B

The Chinese arrived to Southeast Asia as immigrants in two major waves: the first wave (late 15th - 16th century) was characterized by Chinese men who traveled mainly from Fujian province, spoke Hokkienese, and married local women, by contrast, the Chinese in the second wave (late 19th - early 20th century) came from a variety of provinces in China, and spoke various dialects of Chinese (Liu, 2012).

Some countries, where overseas Chinese settled down and made them their homes, took their presence into account and have pursued policies of multiculturalism and multiracialism together with bi- or multilingualism, while others have opted for hardline assimilation policies and monolingualism. According to Liu and Ricks, language policy is a symptom of ethnic relations, and thus results from the situation in the country (Liu, 2010). On the other hand, language choices made by decision-makers have major impacts on society. They can facilitate societal integration or foster pluralistic coexistence, but also aggravate interethnic conflict if they are not chosen wisely (Weinstein, 1990). Mishandling of language policies could significantly contribute to war eruption, as was the case in Sri Lanka (Brown, 2003).

Many countries favor policies that reduce the number of languages spoken, because it is believed that societal differences are dangerous and linguistic diversity is an obstacle to nation-building (Rappa, 2006). Although ethno-linguistic diversity can be a source of conflict, language issues are rarely the sole driving force. In Southeast Asia ethno-linguistic diversity is widespread, and so are ethnic conflicts, but problems leading to conflicts have never originated from language differences. In many Southeast Asian countries overseas Chinese were discriminated, persecuted, or even killed, because their communities, not their languages, were seen as a threat. They are often described as the "Jews of the East" because of their business capabilities. Conflicts between ethnic groups, however, often have a language component, since language issues are deeply entwined with political, economic, and other social issues. Groups that are discriminated against politically are often discriminated against also linguistically, as in case of the overseas Chinese (Brown, 2003).

This article attempts to explain the extent of participation and the differences in regard of the presence or absence of the Chinese language in the language policies of Southeast Asian countries with a substantial Chinese minority: Indonesia, Malaysia, Myanmar, Vietnam, the Philippines, Singapore and Thailand; all countries with over one million of ethnic Chinese. 
The approach used in this article is both descriptive and analytical, and offers a comparative review of the language policy structures of various countries throughout Southeast Asia in regard of the Chinese language. More concretely, the author examines the impact of four independent variables, namely the size of the Chinese minority (big vs. small), the extent of the ethnic Chinese' access and participation in the government and politics (included vs. excluded), the type of governance (democratic vs. undemocratic), and the extent of assimilation in terms of language (hardline vs. moderate policies) on the Chinese language participation in the language policies (dependent variable) of Indonesia, Malaysia, Myanmar, the Philippines, Singapore, Thailand and Vietnam (see Table 2). The Chinese language can be reflected in the language policy as both one of the official languages and one of the languages of instruction; as one of the languages of instruction, but not official languages; or neither. It is important to note here that the terms official language and national language are not synonyms. The former is used by the government for administrative purposes and the latter is spoken by a large number of people in that country.

TABLE 2: DEPENDENT AND INDEPENDENT VARIABLES

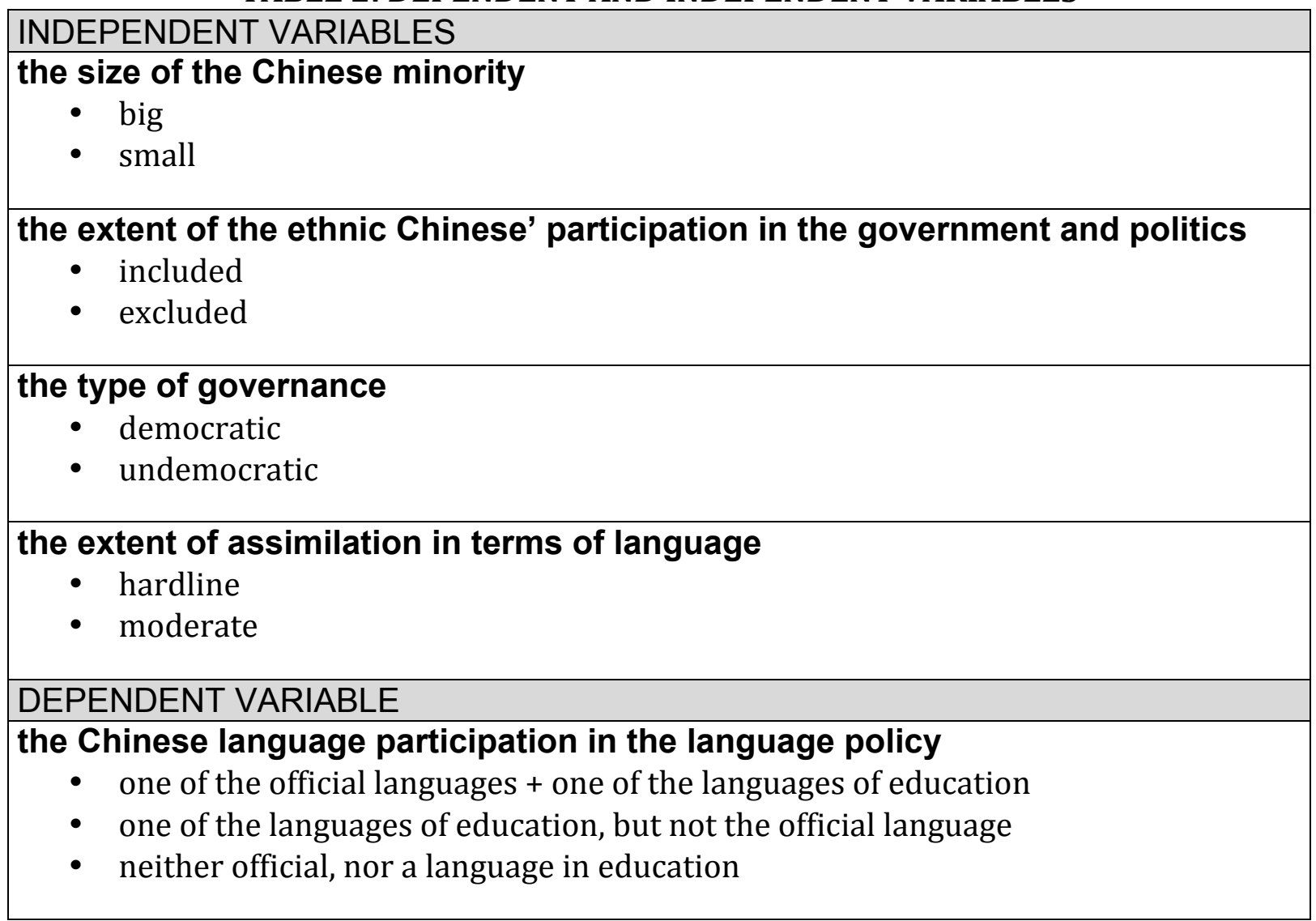

The author argues the following few points. First of all, the bigger the Chinese minority, the bigger the chance of the Chinese language being part of the national language policy. Unfortunately, in many countries reliable data on their populations are not available; for example in Myanmar the last census took place in 1983. For purposes of consistency, data on overseas Chinese were drawn from the Factbook and the Overseas Community Affairs Council R.O.C. from the year 2012. It is important to note that overseas Chinese originate from various regions of China and very often speak unintelligible dialects of Chinese. This may cause a fragmentation of the Chinese community, no matter how big the allover number. The sense of belonging to one Chinese community by the ethnic Chinese may thus be subject to another research. Second, if the ethnic Chinese are included in the government apparatus, it is more 
likely for the Chinese language to be either one of the official languages, or one of the languages of instruction, or both. Because the number of Chinese speakers does not equal the number of ethnic Chinese, this point is very hard to measure. In Thailand, for example, there are many ethnic Chinese politicians who do not speak a word of Chinese. Third, authoritarian regimes are generally associated with less minority language recognition, and thus the Chinese language is less likely to be included in the official language apparatus of an undemocratic regime. And fourth, the harsher the assimilation policies of a country are, the less likely it is for the Chinese language to be part of the official language apparatus.

Brown and Ganguly distinguish between countries that have unipolar, bipolar, and multipolar ethno-linguistic settings. They define a unipolar ethno-linguistic setting as one with one group comprising $90 \%$ or more of the total population, such as the Philippines, Thailand, and Vietnam. In a bipolar setting two groups comprise $90 \%$, such as Malaysia and Singapore. In a multipolar setting no groups taken together comprise $90 \%$ of the population, for example Myanmar and Indonesia (see Table 3) (Brown, 2003). Countries with unipolar ethno-linguistic settings are more prone to mistreat minorities than bipolar and multipolar countries.

TABLE 3: ETHNO-LINGUISTIC SETTINGS

\begin{tabular}{|l|l|}
\hline Country & Ethno-linguistic setting \\
\hline Indonesia & Multipolar \\
\hline Malaysia & Bipolar \\
\hline Myanmar & Multipolar \\
\hline Philippines & Unipolar \\
\hline Singapore & Bipolar \\
\hline Thailand & Unipolar \\
\hline Vietnam & Unipolar \\
\hline
\end{tabular}

Language policies are not static and can shift over time. As for now, Singapore follows since 1957 a language policy of complete multilingualism (4 official languages and 4 in the education system); Malaysia since 1971 incomplete monolingualism (1 official and 3 in education); the Philippines since 1987 incomplete monolingualism ( 1 official and 2 in education); and Indonesia since 1986, Myanmar since 1948, Vietnam since1954 and Thailand since 1938 complete monolingualism (see Table 4) (Liu, 2012).

TABLE 4: LANGUAGE POLICY BY COUNTRY

\begin{tabular}{|l|l|l|l|}
\hline Country & Language policy & Official languages & $\begin{array}{l}\text { Languages in the } \\
\text { education system }\end{array}$ \\
\hline Indonesia & complete monolingual & Bahasa Indonesia & Bahasa Indonesia \\
\hline Malaysia & incomplete monolingual & Malay & Malay, Chinese, English \\
\hline Myanmar & complete monolingual & Burmese & Burmese \\
\hline Philippines & incomplete monolingual & Filipino & English, Filipino \\
\hline Singapore & complete multilingual & $\begin{array}{l}\text { Chinese, English, } \\
\text { Tamil, Malay }\end{array}$ & $\begin{array}{l}\text { Chinese, English, Tamil, } \\
\text { Malay }\end{array}$ \\
\hline Thailand & complete monolingual & Thai & Thai \\
\hline Vietnam & complete monolingual & Vietnamese & Vietnamese \\
\hline
\end{tabular}

The next section gives a more detailed account of specifics on language policy developments in each of the eight countries considered in this research in alphabetical order. 


\section{CHINESE IN INDONESIA}

The Republic of Indonesia with its population of more than 240 million people, spread over hundreds of islands, is one of the most populous countries in the world. There are more than 300 ethnic groups and more than 250 languages spoken in Indonesia (Hartanto, 2013). The country experienced ethnic conflicts, but little violence around language issues (Rappa, 2006). Since 1986, the official language has been Indonesian (Bahasa Indonesia), a modified version of Malay. It is also the language of instruction in schools. Although most Indonesians speak local languages, such as Javanese, as their first language, Indonesia only recognizes a single official language. Other languages are recognized neither at national level nor regional level. In the 2006, the notion of the local content subject in elementary schools was loosely defined, but strangely many elementary schools throughout Indonesia opted for English rather than ethnic languages of the region (Chaedar Alwasilah, 2013).

Chinese Indonesians or orang Tionghoa, originated from various Chinese ethnic groups from the Fujian and Guangdong provinces in southern China. Four major Chinese dialects are spoken in Indonesia: Mandarin, Hokkienese, Hakka, and Cantonese. According to Indonesia's 2000 census there were over 1.7 million self-identified ethnic Chinese $(0.9 \%$ of the country's population), mostly living in Java (Indonesia: Population and Administrative Divisions, 2003). This figure is wildly under-reported since many Chinese are reluctant of identifying themselves ethnically and the offspring of mixed ethnicity does not consider itself as ethnic Chinese. This may have resulted from the deep-rooted discrimination against ethnic Chinese in Indonesia. According to the Overseas Community Affairs Council R.O.C., there are eight million Chinese living in Indonesia (Overseas Community Affairs Council R.O.C., 2012).

In the early 17th century, when the Dutch arrived, settlements of Chinese traders and merchants already existed along the coast of Java. Their population grew rapidly during the colonial period because initially the Dutch contracted Chinese workers for the purpose of building and expanding of the capital of the Dutch East Indies. Following the 1740 Batavia massacre, however, the Dutch placed a quota on the number of Chinese who could enter the Dutch colony. The Chinese were perceived as temporary residents and citizenship was only conferred upon them in the 1946 Citizenship Act after Indonesia became independent. Ethnic Chinese born on Indonesian soil during the colonial period were regarded by the newly independent state (jus soli) as Indonesian citizens, while and at the same time by China (jus sanguinis) as Chinese citizens. This issue was solved by the Dual Nationality Treaty, signed in 1955 by both Indonesia and China. Those who wished to remain Indonesian citizens were allowed to renounce Chinese citizenship; 390,000 decided to do so, and another 60,000 decided to leave (Purdey, 2006). Following the anti-communist violence in the 1960s, many of the Chinese, who originally decided to stay, left Indonesia.

Ethnic Chinese communities in Indonesia were attacked several times by various groups throughout history. After introduction of soft-authoritarian rule in 1959, restrictions were placed on the non-indigenous population in order to boost indigenous businesses, and following protests, ethnic Chinese communities in West Java were attacked. A few years later some 500,000 people, including many Chinese, were killed in an anti-communist purge following a failed coup d'état suspected as being communist-led. The elimination of the Indonesian Communist Party was pivotal in the transition to the "New Order" and Suharto's rule. General Suharto introduced the Pancasila ideology (five inseparable and interrelated principles) along with several policies banning any expression of Chinese culture or traditions, and requiring the adoption of Indonesian names. Mandarin-language press and writings were severely limited and Chinese schools banned altogether. Anti-Chinese riots broke out again in 
the 1990s, and were followed by another wave of emigration of ethnic Chinese. Several communities have emerged in the second half of the 20th century in Western countries. However, they identify more with Indonesia than their Chinese heritage (Ling, 2008).

The new reform government following Suharto's resignation in 1998 has gradually introduced major reforms and attempted to attract Chinese Indonesians who had fled the country to come back. This was part of the effort to build up the badly destroyed economy since the Chinese have been believed to dominate the business sector (Purdey, 2006). Also, the ban on Chinese schools and the practice of Chinese traditions was lifted and Chinese is now being taught in many schools. Since 2002, the Chinese New Year is marked as a national holiday and since 2006, Chinese Indonesians are even eligible to run for president (Suryadinata, 2008). However, they remain politically weak with only few representatives in national politics. During Megawati's term as president, one of the coordinating ministers was an ethnic Chinese, and in President Susilo's cabinet, one of the ministers was a female ethnic Chinese.

\section{CHINESE IN MALAYSIA}

The Federation of Malaysia is a multiracial country with a population of a little less than 30 million and three major ethno-linguistic groups: Malays, Chinese and Indians. Ethnic Malays comprise almost $60 \%$ of the population, while Chinese make up a quarter of the population, and Eurasians and Indians make up the remaining 7.5\% (Rappa, 2006). Although there are many ethno-linguistic groups in Malaysia and English is widespread in law, trade, commerce, and education, Malay, from the Malayo-Polynesian language family, is the official language of Malaysia and is enshrined in the Malaysian constitution.

As of 2010, almost seven million people in Malaysia self-identified as Chinese. This figure excludes their offspring of mixed ethnicity (Overseas Community Affairs Council R.O.C., 2012). The Chinese Malaysians speak a variety of dialects, mainly Hokkienese (35\%), Hakka (24\%), Cantonese (18\%), Teochow (11\%), and a few others, such as Hainanese and Hokchiu (Hing, 2000).

Chinese immigration to Malaysia started as early as the 15th century when the Sultan from Malacca married a Chinese princess who was accompanied by several hundred Chinese. More Chinese arrived after the Fujian massacre in the 1650s. The late 19th century and early 20th century saw the biggest wave of Chinese immigration, mainly from the British controlled areas of Fujian and Guangdong provinces, to work in tin mines and rubber plantations. The latest wave of Chinese immigration took place in the 1990s, although much smaller than the previous ones.

With the transition from being temporary immigrants to a more permanent community at the turn of the 19th century, the Chinese established their first schools in Penang, Malacca, and Singapore (Palanca, 2002). Chinese schools at that time were recognized by China as an integral part of its education system and after 1911 supervised by the Kuomintang party from Nanjing. After violent anti-Japanese demonstrations in 1919 by ethnic Chinese in Malaya, the British colonial government required Chinese schools to register with the Education Department and examined textbooks for Kuomintang propaganda (Palanca, 2002).

The first Chinese women arrived in Malaysia in the 20th century and the ratio increased from approximately 1 to 5 in the first years of the 20th century, from 1 to 3 in the 1930s, and became more or less balanced in the 1960s (Lee, 2000). The proportion of the Chinese population born in Malaysia increased dramatically since then. Today, they make up a highly 
disproportionate percentage of Malaysia's professional and educated class and control an estimated $70 \%$ of the Malaysian economy (Chua, 2003).

During the decolonization period the ethnic Chinese closed ranks with the Malays in demanding independence. The major Chinese political party, the Malaysian Chinese Association, was part of the Alliance Party (from 1973 the National Front), which became the ruling party when Malaya became independent. Since then there have always been a few cabinet ministries headed by ethnic Chinese (Palanca, 2002).

Soon after attaining independence, the cleavages between the Malays and the Chinese resulted in racial riots followed by the authoritarian implementation of the New Economic Policy and the start of Tun Razak's rule. He dissolved the parliament and Malaysia was governed by an authoritarian executive council. He wanted to equalize opportunities for all people and lessen the gap between them by distinguishing between the bumiputras (indigenous Malay) and nonbumiputras and creating a quota system for employment and education opportunities for the Malays. This policy of open discrimination is to this day still being implemented (Rappa, 2006).

Chinese as a medium of instruction has been allowed within the national primary school system, but not for secondary schools. Ethnic group secondary schools were converted after independence to standard-type secondary schools, where teaching of the Chinese and Indian languages was allowed if there was a demand from at least 15 students. The government, however, does not allow establishing more such schools and the number has been the same since the 1960s (Palanca, 2002). Moreover, since the implementation of the National Language policy in 1977 all secondary schools have to use Malay as medium of instruction. Before, both Malay and English could be used. There is an exception, high schools with Mandarin as medium of instruction, but these are not part of the national education system and receive no subsidy. Graduates from such schools cannot enter regular Malaysian universities and have to enroll in private colleges supported by foreign institutions that grant the degrees, or study overseas (Palanca, 2002). In 2002, a proper Chinese university (Universiti Tunku Abdul Rahman) was launched, and Chinese Malaysians do not have to go abroad anymore if the wish to study in Chinese (Rappa, 2006).

\section{CHINESE IN MYANMAR}

The Union of Myanmar is comprised of over 100 ethno-linguistic groups with their own languages and dialects divided into eight major distinctive ethnic groups. Apart from the indigenous national languages, a significant number of Chinese and Indians are living in Myanmar. The Chinese population, excluding those of mixed background, with over 1 million people comprises about 3\% of the total population of 5 million (The World Factbook: Burma, 2013). The actual figure is believed to be much higher. Many Chinese have registered themselves as ethnic Bamar to escape discrimination. Moreover, an estimate of two million illegal Chinese immigrants has flooded the country since the 1990s (Rieffel, 2010). In 2015, results of the 2014 census will be released, until then the only numbers available are census results from 1983.

Chinese traders traveled as far as the former capital city, Yangon, early on, but they only settled down there in the 19th century when the British colonial administration encouraged immigration to the region. New opportunities and enterprises attracted many Chinese. Because they were of Sino-Tibetan origin, the same as the Bamar, and were Buddhists, they integrated well into Burmese society. 
From 1935 until the end of British rule, the Chinese were represented in the colonial legislature, the House of Representatives (Vandenbosch, 1947). During this period, there was also a sharp rise in the number of private Chinese language schools, primarily teaching Mandarin Chinese, in Burma, from 65 in 1935 to 259 in 1953 and 259 at its peak in 1962 (Murray, 2009).

In 1948, Burma emerged as an independent democratic nation. Independent Burma was one of the first countries to recognize the People's Republic of China as a nation. However, Burmese Chinese were treated by the post-independence government as aliens and were issued foreign registration cards in a tiered citizenship system. Many more Chinese fled to Burma when the Chinese Communists expelled the Kuomintang. Although, the Burmese government fought and removed the armed Kuomintang (they left for Taiwan), anti-Chinese riots continued throughout the 1970s.

Following the Socialist coup d'état in 1962 led by Ne Win, Burma entered a period of military dictatorship. Under the "Burmese Way to Socialism" all major industries were nationalized and foreigners, including the non-citizen Chinese, were not allowed to own land, send remittances, get business licenses and practice medicine (Murray, 2009). The 1982 Citizenship Law further restricted citizenship for Burmese Chinese. This severely limited them from attending professional tertiary schools (especially those without full citizenship and those holding foreign registration cards). Moreover, Chinese-language schools in Burma were banned. Such policies led to the decline of Mandarin speakers, as well as the beginnings of a major exodus of Burmese Chinese to other countries. Although the number of Chinese schools is growing again today because of the importance of Mandarin Chinese, many wealthy Burmese Chinese send their children nowadays overseas for advanced studies.

After independence, Burma chose the Burmese language as its official language and the medium of instruction at all public schools throughout the country. The Burmese language is spoken by about $69 \%$ of the population. There are many ethnic languages (belonging to the Austro-Asiatic, Malay-Polynesian, Sino-Tibetan, or Tai language families); among them top language groups are Shan 8.5\%, Karen 6.2\%, Rakhaing 4.5\%, Mon 2.4\%, Chin 2.2\%, and Kachin $1.4 \%$, according to 1983 census (Lwin, 2011). The Burmese language became compulsory in education. Indigenous minority language teaching was allowed in schools until 1962. From 1962 to 2010, successive governments have sought to Burmanize and assimilate other groups in the name of national unity and forbid teaching minority languages at schools. That remains the case until today. The newest 2008 Constitution states that the Burmese language is the official language and does not recognize indigenous national languages as official languages in their states. However, some of these indigenous languages, such as the Kachin, Karen, and Shan languages, have been used as medium of instruction at schools run by the respective minority dissident groups. The English language is a compulsory subject in primary and secondary schools. In 2011, the Upper House of the parliament passed a Private School Bill, which permits the opening and operating of secondary schools, and the teaching of ethnic languages. It allows ethnic groups to teach their language as an additional subject in private schools. However, the Bill does not allow opening and operating at primary school level (Lwin, 2011).

\section{CHINESE IN THE PHILIPPINES}

The population of the Republic of the Philippines is, as a result of several-centuries-long foreign rule, one of mixed races with Spanish, Chinese, American and other heritages. The unmixed Chinese population comprises less than 2\% of the total population of over 105 million, but there are significantly more Chinese Filipinos with Chinese ancestry. 
The country has been unified into its present form during the Spanish colonization era that lasted for more than three centuries. After the Spanish-American War, control of the Philippines was transferred to the US. During World War II, it was occupied by Japan, and after war emerged as an independent nation. Corruption and nepotism, as well as civil unrest, characterized the following decades, especially under Ferdinand Marcos. In 1986, the peaceful People Power Revolution ousted the corrupt dictator and a returned the country to democracy.

Due to the separation of communities from one another by sea and mountain, various ethnicities and languages have emerged in different parts of the country. There are over 70 ethnic groups and migrant populations, and over 170 languages that are spread throughout the islands. Most of the languages are indigenous languages that belong to the Western MalayoPolynesian subfamily of languages, except for three foreign languages: English, Spanish, and Hokkienese (Castro, 2011). Although there is a substantial Chinese minority in the Philippines, Mandarin is not widespread.

Chinese traders from Fujian had visited the Philippine islands long before the arrival of the Spanish. However, their interaction with the local Filipinos was generally limited to economic and trading issues. During the American colonial period, Americans restricted Chinese migration to the Philippines to prevent migrants from moving to the US with the Chinese Exclusion Act of 1882 (Williams, 2004). During this time, thousands of Chinese from Fujian migrated with the help of other Chinese Filipinos to the Philippines to avoid the worsening situation in China. The majority of today's unmixed Chinese Filipinos stems from this era. (Weightman, 1960). It was during this time that more Chinese women started migrating to the Philippines. In 1903, the census showed a female-male ratio of 13 to 1000, which grew to 43 to 57 in 1960s, and became balanced only in the 1970s (Palanca, 2002). Once the Chinese became a settled community, they established schools, which China considered an integral part of its education system and cultivated Chinese national consciousness in their students. After the World War II the number of Chinese schools in the Philippines increased from 58 in 1935 to 150 in 1970 (Hsiao, 1998).

Fighting a common enemy, the Japanese, in the World War II moved the ethnic Chinese migrants and the indigenous Filipinos to unification (although the Chinese never played a major role), and the Chinese Filipino started to regard the Philippines as their home. After the Philippines gained independence in 1946, the new government introduced policies favoring natural born Filipinos over naturalized Filipinos, and thus limited Chinese economic opportunities. A few years later, the 1973 Constitution prohibited alien schools, and so primary and secondary Chinese schools, which were until then governed by the Ministry of Education of the Republic of China, were transferred under the jurisdiction of the Philippine government and ordered to limit Mandarin, history, and culture subjects to two hours per day (Palanca, 2002). In 1975, President Marcos relaxed the naturalization policy and many Chinese were able to become Philippine citizens. However, only very few could afford the cost and were willing to go through the process of acquiring citizenship (Palanca, 2002).

Today, Chinese Filipinos are known as Tsinoy from the words Tsino for Chinese and Pinoy for Filipino. They have obtained citizenship and have no longer restriction in choice of residence or profession. Although there are some public figures with Chinese ancestry, such as President Corazon Aquino, President Gloria Macapagal-Arroyo, and Manila Bishop Cardinal Sin, there are only few ethnic Chinese in government service (Chinatownology, 2007-13). 
The 1987 Constitution established Filipino (before called Pilipino) the national language of the Philippines. For purposes of communication and instruction, the official languages are Filipino and English. The regional languages can be used as auxiliary languages in the first two grades (Espiritu, 2011).

It is very common to hear Chinese Filipinos mix Hokkienese, English and Tagalog in their everyday conversation. Using Chinese as a medium of instruction ended with the Filipinization process. Chinese schools continue to exist; they differ from Filipino schools only in that their students are ethnic Chinese. For most of these students Tagalog became their first language and they may have picked up some Hokkienese from their relatives; Mandarin is a foreign language to them (Palanca, 2002).

The Macapagal-Arroyo's administration has encouraged including Mandarin in the educational curriculum of colleges and universities in the Philippines as an elective language course to prepare the future workforce for the global arena (Rappa, 2006). In 2012, the Department of Education included Mandarin as one of five foreign languages that can be taught in public high schools in addition to English (the other four: Spanish, French, Japanese, and German) (Tort, 2013).

\section{CHINESE IN SINGAPORE}

The Republic of Singapore is an island country with a linguistically and ethnically diverse population of about 5.4 million. The government recognizes three major ethnic communities: Malay, Chinese (various Chinese dialect groups), and Indian (various Indian language groups). The Chinese community always was, and still is, the largest ethnic community in Singapore. The Chinese make up 74\%, Malays 13\%, and Indians 9\% (Census of Population 2010).

Throughout history Singapore was part of various local empires until 1963 when it declared independence from the United Kingdom and together with other British territories formed Malaysia. Singapore became an independent city-state in 1965 after being ejected from the Federation of Malaysia due to political differences between the Singapore government and the central government over issues concerning the management of ethnic relations. Singapore's view was that granting of special rights would create more problems (Rappa, 2006). Instead, Singapore's leadership embraced a vision of a multiracial and multicultural society. Throughout Singapore's history as a sovereign state, its politics has been dominated by the People's Action Party and often described as a hybrid regime with both authoritarian and democratic features. Because Singapore has no natural resources, Malaysian politicians expected Singapore to fail within the first two years away from the Federation. Today, Singapore is described as one of the four Asian Tigers.

Chinese immigrants arrived to Singapore during the 19th century and early half of 20th century mostly from the southeastern coast of China in the provinces of Fujian, Guangdong and Hainan, and are typically known as 'native' Singaporean Chinese. The recent years saw Singapore experience another wave of migration from different parts of China.

Although the Chinese constitute the majority of the population, the leadership has accepted Malay language as the national language and English as the language administration. Although the government views linguistic diversity as a problem for nation-building, Singaporeans are encouraged to be bilingual in English and a mother tongue that is officially assigned to them on the basis of their father's ethnic identity. Three major official mother tongues are recognized: Mandarin, Malay, and Tamil (Rappa, 2006). English cannot be officially considered a mother tongue; it is the lingua franca for inter-ethnic communication. Altogether, there are, according 
to the Independence Act (1965), four official languages in Singapore: Malay, Mandarin, Tamil and English. The language policy as a whole in Singapore is shaped by four main ideas. The first idea is the belief, similar to many other countries, that linguistic diversity is an obstacle to nation-building. The second idea is that respect and equal treatment of each ethnic group (each community has its own mother tongue) is the key to maintain harmony among Singapore's ethnically diverse population. The third idea acknowledges the important role of English in the world economy. The fourth idea is the ideology of pragmatism and the importance of solving crises that may occur along the way (Eisenstadt, 1973).

In the past, Chinese education, due to its close links with the Communist Party of Malaya, was associated with Chinese chauvinism and was thus minimized by the government. First Chinese schools were established in the 19th century. They used various southern Chinese languages, such as Hokkienese, as languages of instruction. In the 1920s, Chinese schools in Singapore, like in many other schools in Southeast Asia, changed its medium of instruction to Mandarin Chinese. In 1953, the first overseas Chinese-medium University in Singapore, Nanyang University, was established. Since the early 1980s, the government gradually abolished the Chinese-medium education system in Singapore. Today, the education system follows an English-knowing bilingualism, where students learn English as well as their mother tongue (taught as a second language). Since 1985, when the second deputy Prime Minister, Ong Teng Cheong, highlighted the economic importance of Mandarin, there is great emphasis on Chinese language learning (Rappa, 2006).

English is growing as the home language of many Chinese Singaporeans, making it difficult for them to learn Mandarin at the level that was originally demanded of them by the state. Also, the existence of so many mutually unintelligible Chinese dialects is problematic. There are six major dialects spoken in Singapore: Cantonese, Foochow, Hainenese, Hakka, Hokkienese, and Teochiu. This, like in all other Southeast Asian countries where Chinese reside, creates a fragmentation of the ethnic Chinese community. However, under the 1979 Speak Mandarin Campaign, Chinese in Singapore have increased their use of Mandarin in place of other Chinese dialects (Brown, 2003). In an attempt to make Chinese Singaporeans Mandarin-speaking in a short span of time, other Chinese dialects have been banned from the media. Despite the government's success in promoting the use of Mandarin, there is still at present a strong sense of attachment to the other Chinese dialects at the grassroots level.

Today, several Chinese associations are active in Singapore, mainly the Singapore Federation of Chinese Clans Association, which has mostly a cultural role; and the Singapore Chinese Chamber of Commerce and Industry, which looks after the business interests in the Chinese community. There are many other Chinese cultural and religious organizations active in Singapore, such as the Singapore Chinese Calligraphy Society, the Nanyang Confucian Association, and the Singapore Taoist Federation.

\section{CHINESE IN THAILAND}

The Kingdom of Thailand is a constitutional monarchy, headed by King Rama IX, who has reigned since 1946. The kingdom, formerly known as Siam, was founded in the late 18th century. It is the only country in Southeast Asia that has never been colonized by any European power. Thailand is both multilingual and multiethnic, with a population of over 65 million and with about 80 languages (Rappa, 2006). According to the 2010 Census, 95.9\% of the population in Thailand is comprised of Thai nationals, and the rest is composed of Burmese, Laotian, Cambodian or Chinese (The 2010 Population and Housing Census). However, accodring to the Overseas Community Affairs Council R.O.C., in 2012 there were over seven 
million ethnic Chinese living in Thailand, about $10 \%$ of the population. Other estimates are as high as nine million (CIA Factbook). Whatever the exact number, Thailand is home to one of the largest and best-integrated overseas Chinese communities in the world. The Thai Chinese have been deeply ingrained into the Thai society for the past 400 years. Even the founder of the present Thai royal family was partly Chinese. It has been estimated that about $20 \%$ of the Thai population has some form of Chinese ancestry (Smalley, 1994).

Although all Thais speak Thai, a homogeneous 'Thai people' is very much a social construct. Standard Thai, a language associated with the elites and Thai royalty, is the official language of Thailand and the primary medium of instruction in the school system. The official policy does not allow any other language to be used at school, though in the rural areas, teachers sometimes find they need to resort to the local language in order to proceed with the class (Rappa, 2006).

Chinese traders began arriving in Ayutthaya in the 13th century mostly from Fujian and Guangdong, and in the 18th century from Chaozhou. The Chinese community in Thailand grew from 230,000 in 1825 to 792,000 by 1910 (Stuart-Fox, 2003). Most of the Chinese immigrants came from Southern China, plagued by floods or drought. The most significant influx of Chinese into Thailand took place in the latter half of the 19th century, when large numbers of Chinese immigrants from China came over to work as laborers. A number of these immigrants stayed on. In the early stage of Chinese immigration, the bulk of immigrants consisted of men who married local women. Chinese women only began arriving to Thailand in the early 20th century. The offspring of these Chinese-Thai couples subsequently married local Thais as well, thus leading, in some cases, to a complete assimilation of the Chinese (Rappa, 2006). The assimilation in the case of the Chinese (in contrast to the Malays) was also helped by the influence of religion, Buddhism, which both the Chinese and Thais practice.

In the early 20th century, King Rama VI further enforced assimilation of the Chinese community by requiring the adoption of Thai surnames. The Chinese had to choose between setting aside their identity or being regarded as foreigners; most opted for becoming Thai. In 1918, his government passed a law requiring that private Chinese schools teach standard Thai.

Throughout Thailand's history rulers have exercised absolute power. In 1932, a bloodless coup created a constitutional government with a prime minister. During the reign of King Prajadhipok, Siam changed from an absolute monarchy to a constitutional monarchy. The king continues to wield important social and cultural influence in a largely symbolic role.

Under Phibulsonggram's military dictatorship in 1939, the name of the kingdom, 'Siam', was changed to 'Thailand' and Thai was established as the only national language. Chinese schools were limited to two hours of Chinese language per week. Other languages are only available as taught subjects, though recently, some international schools with English as the medium of instruction have been established (Ho, 2000).

The Thai Chinese have been extremely successful in business. Between the two World Wars, Thailand's major exports were under Chinese control. This was also the time when the Chinese in Thailand suffered the most discrimination. The military dictatorship imposed a range of taxes and controls to Chinese businesses. Nevertheless, they were still encouraged to acquire Thai citizenship; by 1970, most of the Chinese born in Thailand had done so.

During the Cold War, Thailand went through decades of political instability characterized by coups as one military regime replaced another, but eventually progressed towards a stable 
democracy in the 1980s. Thai Chinese today are well represented in Thai business, commerce, and politics. Most of Thai Prime Ministers were at least of partial Chinese origin. Due to their assimilation, all ethnic Chinese in Thailand speak Thai and their original native dialects are progressively dying out. In the 2000 census, only 231,350 identified as speakers of a variant of Chinese (Guan, 2007). In 2010, there were only 111,866 people speaking Chinese at home (The 2010 Population and Housing Census). Mandarin is mainly acquired as a second language at schools where it is offered as an elective subject. Some Chinese parents even send their children abroad for a Chinese-medium education, while others have accepted the fact that in order to prosper in Thai society, knowledge of Standard Thai is indispensable, and a lack of proficiency in Thai could be a major handicap for business negotiations in Thailand (Rappa, 2006).

\section{CHINESE IN VIETNAM}

With about 90 million inhabitants, the Socialist Republic of Vietnam is one of the most populous countries in the world. Vietnam is multilingual and multiracial with 54 main ethnic groups, some of which have less than 1,000 members. In the 1990s, the Kinh (Viet) made up 86.8\% of all inhabitants (Brown, 2003). Besides Vietnamese (the native language of the Kinh) there are many other languages. In the past, most languages used Chinese characters as a basis for their writing system. The French introduced during the occupation period a romanized system of writing (quoc NGU) to the Vietnamese and other languages spoken in Vietnam (Brown, 2003).

Before 1945, bilingualism and multilingualism were widespread, but all these languages were secondary to French. In 1945, after independence the Vietnamese language (part of the AustroAsiatic language family) was adopted as the national language. In education, the Vietnamese language replaced French as the language of instruction at every level of schooling. Ho Chi Minh considered Vietnamese an important symbol of national identity. In the south, promotion of the Vietnamese language was much slower.

Ethnic minorities altogether account for $30 \%$ of the entire Vietnamese population (Buøi Khaùnh Theá, 2003). In 1980, the Decision 53-CP was implemented; it mandated that Vietnamese be the common language for every ethnic group in the country, but also urged the use of different common languages for different regions (Buøi Khaùnh Theá, 2003).

Bilingual educational curricula in Vietnam are used in some primary schools. As of the early 1990s, only a limited number of schools continued teaching minority scripts (Brwon, 2003). Languages like Chinese and French, both used extensively in the past, were relegated to the status of foreign languages.

Ethnic Chinese in Vietnam are usually referred to as Hoa people. They are estimated to comprise about 1\% of Vietnam's population. Vietnam shares a long border with China as well as a long history of Chinese rule of Vietnam (111 BC to 938 AD). After the Chinese occupation ended, contact continued due to trade relations between Vietnam and China. Over the centuries many Chinese men arrived to Vietnam and married native women. Chinese immigration into Vietnam visibly increased in the second half of the 19th century following the French colonization of Vietnam (Cochinchina) and the signing of the Convention of Peking, due to which the rights of Chinese to seek employment overseas were officially recognized by the Chinese, British and French authorities. In 1874, the French established a special Immigration Bureau in Saigon that required Chinese immigrants to register with an existing Chinese clan that was willing to provide sponsorship for them (Khánh, 1993). This approach was a mix of 
control and encouragement. Due to protests from the Chinese this office had to close down. As the Chinese could come and go freely, their number in Cochinchina rose from 44,000 in 1873 to 56,000 in 1889 (Khánh, 1993). The Influx of Chinese workers continued until the middle of the 20th century.

With the division of the country in 1954 the South became the Republic of Vietnam and the North the Democratic Republic of Vietnam under Ho Chi Minh. Statistics about the Chinese in Vietnam from this time are not widely available, and the ones that are, are not reliable. They are, however, estimated to have controlled between $70 \%$ and $80 \%$ of the South Vietnamese economy before the fall of Saigon. In the year of reunification, the amount of Chinese in Vietnam was $1,236,000$ (2.6\% of the total population) with the majority of them living in the South (Khánh, 1993).

From 1975 until the major economic reforms of 1986, Vietnam followed socialist policies of a high command economy and political centralization. During and after the Sino-Vietnamese War, the Chinese were encouraged to leave Vietnam. In the aftermath of the Vietnam War, when ethnic Vietnamese were establishing new economic zones, the Hoa became scapegoats for the Communists. Many Hoa were persecuted and had their businesses and property confiscated. As a result, they fled the country as boat people (mainly the Hoa from the South). The situation improved in the 1990s; poverty among the Hoa has not only decreased more than for any other ethnic minority, it is even lower than the poverty level for majority Kinh (Minority Rights Group International, 2008).

At present Chinese Vietnamese comprise a small percentage in the modern Vietnamese economy, it is now mostly Vietnamese-run. The ethnic Chinese, however, comprise a high percentage of Vietnam's educated and upper class. Vietnamese authorities still do not allow private schools teaching Chinese to go beyond teaching the actual language. This results in some Hoa attending these schools in order to preserve their language and culture. Many ethnic Chinese seek higher education abroad.

\section{CONCLUSION}

Throughout history, Chinese nationals have continuously immigrated to Southeast Asia. Two major immigration waves took place in late 15th and throughout the 16th century and in the late 19th and early 20th century. Emigration was caused by corruption, wars and starvation, as well as invasion from foreign countries. Most of the emigrants were illiterate peasants or manual workers. Those who left China under the Qing Dynasty without the Administrator's consent were considered as traitors. After the establishment of the Republic of China, these rules were abolished the Chinese could migrate without repercussion. The take-over of China by the Communist Party, however, meant that going back to China was restricted and thus many ethnic Chinese made their host countries in Southeast Asia their permanent homes. More liberalized emigration policies were enacted in 1983, a result of the economic open-door policy, and facilitated the legal departure of many Chinese who wished to join their overseas Chinese relatives living abroad. Overseas Chinese in Thailand, Indonesia and Malaysia constitute the three largest Chinese communities in the world.

This article explains the differences in regard of the presence or absence of the Chinese language in the language policies of Southeast Asian countries with a substantial Chinese minority (over one million of ethnic Chinese residing in one country). The author came to a conclusion that there is no correlation between the size of the Chinese minority, calculated as a percentage of the total population (see Table 5), and the representation of the Chinese language in the national language policy. (In this research an overseas Chinese community is 
considered as big if it comprises over $10 \%$ of the total population or over five million people in one country.) The reason for this is that the Chinese minority is language-wise fragmented; overseas Chinese throughout Southeast Asia originate from various regions and speak a great variety of unintelligible Chinese dialects.

TABLE 5: AMOUNT AND PERCENTAGE OF OVERSEAS CHINESE

\begin{tabular}{|l|r|r|r|}
\hline Country & Total population & Chinese population & $\%$ of the total \\
\hline Indonesia & 248216193 & 8120000 & $3 \%$ \\
\hline Thailand & 67091089 & 7510000 & $11 \%$ \\
\hline Malaysia & 29179952 & 6780000 & $23 \%$ \\
\hline Singapore & 3771000 & 2794000 & $74 \%$ \\
\hline Philippines & 103775002 & 1410000 & $2 \%$ \\
\hline Myanmar & 54584650 & 1060000 & $1 \%$ \\
\hline Vietnam & 91519289 & 1000000 & $1 \%$ \\
\hline
\end{tabular}

Source: The total number of population is taken from the CIA Factbook (2012) and the Chinese population from the Overseas Community Affairs Council R.O.C. (2012), with the exception of Singapore, where numbers from the 2010 Census were used.

Another factor considered in this research is the extent of the ethnic Chinese' access to politics and participation in the government. There was, however, found no correlation either; the extent of participation of the ethnic Chinese in the government of their host country makes no difference in regard to the country's language apparatus and whether Chinese is included in it, because Chinese speakers differ in number from ethnic Chinese meaning that many ethnic Chinese have over the years been assimilated into the host country's population.

Based on the assumption that linguistic diversity is also an obstacle to nation-building, all countries attempt using some sort of assimilation policies. Types of assimilation policies (hardline or moderate) adopted by the host countries play an important role in the question whether the Chinese language is or is not represented in the language apparatus. Some Southeast Asian countries have applied moderate assimilation language policies, while other resorted to hardline assimilation, as is the case of Myanmar, Thailand, Vietnam, and Indonesia. Here, the type of governance plays an important role. In countries with authoritarian regimes the Chinese language is not included in the official language apparatus. But because language policies are not static, it is not enough to evaluate the regime type of current days. For example in Thailand, although it is today a democracy, it has a monolingual language policy, which is inherited from times when it was ruled by a military dictatorship. All of the above-mentioned four countries with hardline assimilation practices are or were governed or ruled in the past by dictatorships, so hardline assimilation language policies hardly come as a surprise. Two exceptions are Malaysia and Singapore, which both did not resort to hardline policies although they were under authoritarian rule in the past, and Singapore, under the People's Action Party, continues with some authoritarian features in the present. Singapore has embraced a multilingual vision that tolerates and even promotes the use of several languages. The imposition of Malay and English on a predominantly Chinese population, however, has not given great weight to the linguistic preferences of the public.

Political leaders have a choice of two types of instruments when turning their long-term vision (unilingual, bipolar, or multilingual) to reality: coercive instruments (legal prohibition, political repression, economic pressure, imposition of martial law, use of military force) or inducement (persuasion, co-optation). Many of the Southeast Asian countries with a substantial ethnic 
Chinese minority opted for the former, although inducement may have been more effective than coercion (Brown, 2003). Such hardline assimilation policies effectively wiped out the Chinese language in Thailand. Also Vietnam's imposition of Vietnamese as a national language has been energetic, and minority languages have not been adequately promoted. On the other hand, the more moderate the assimilation policies in regard to language, the greater the chance that the Chinese language will be one of the official languages or a language of instruction. Indonesia successfully promoted Bahasa Indonesia as a national language, but it has done so without posing undue threats to minority languages. Bahasa Indonesia is seen as ethnically neutral; it does not privilege any one ethno-linguistic group above the rest. In the Philippines, the national language project has instituted Pilipino, later in the 1970s Filipino, as the national language, and has not engaged in concerted efforts to eliminate minority languages.

Language policies in Southeast Asia are based on three beliefs: language policies are symptoms of ethnic relations, they are legacies of colonialism, and are instruments for nation-building (Liu, 2012). Governments have during their nation-building period incorporated three different visions in regard to language, not always taking the ethno-linguistic settings of the country into account: Malaysia and the Philippines opted for the incomplete monolingual language policy, Indonesia, Myanmar, Thailand and Vietnam for the complete monolingual, and only Singapore chose complete multilingualism.

The Chinese language (Mandarin) is an official language only in Singapore. Although Chinese is used in education in Singapore, the only country outside of Greater China (China, Hong Kong, Macau, and Taiwan) where education using a Mandarin-medium of instruction comparable to that of China, Hong Kong or Taiwan is available today is Malaysia. However, it is not part of the national system and gets no subsidy from the government. It is only allowed at the primary level, and although Chinese secondary level schools exist, they are excluded from the national education system. In other countries, Chinese schools exist in a different way, mostly only teaching Mandarin as a foreign language. Singapore with a majority of Chinese inhabitants is an exception, the Chinese language is taught as one of three officially assigned mother tongues. In the last couple of decades the importance of Chinese has increased, and many governments have recognized the importance and benefits of learning the language. Recently, in many Southeast Asian countries, where the instruction of Chinese was forbidden in the past, schools teaching Mandarin opened with the support of their respective governments and this trend is supposedly going to continue in the near future.

\section{REFERENCES}

2003. Indonesia: Population and Administrative Divisions. The Permanent Committee on Geographical Names. October. http://www.pcgn.org.uk/indonesia-\%20population\&admindivs-\%202003.pdf

2007-13. From Sangley to Tsinoy: Journey of Overseas Chinese in the Philippines. Chinatownology. http://www.chinatownology.com/overseas_chinese_philippines.html

2008. World Directory of Minorities and Indigenous Peoples - Vietnam: Chinese (Hoa). Minority Rights Group International. http://www.refworld.org/docid/49749c7f8.html

2010. The 2010 Population and Housing Census: Executive Summary. National Statistical Office of Thailand. http://popcensus.nso.go.th/file/popcensus-10-01-56-E.pdf

2010. The 2010 Population and Housing Census. National Statistical Office, Ministry of Information and Communication Technology, Thailand.

2012. Statistics: Overseas Chinese Population, Overseas Community Affairs Council R.O.C.. http://www.ocac.gov.tw/english/public/public.asp?selno=8889\&no=8889\&level=B

2013. The World Factbook: Burma. Central Intelligence Agency. https://www.cia.gov/library/publications/theworld-factbook/geos/bm.html 
2013. The World Factbook: Singapore. Central Intelligence Agency. https://www.cia.gov/library/publications/the-world-factbook/geos/sn.html

2014. Census of Population 2010 Statistical Release 1: Demographic Characteristics, Education, Language and Religion. Department of Statistics, Ministry of Trade \& Industry, Republic of Singapore.

http://www.singstat.gov.sg/publications/publications_and_papers/cop2010/census_2010_release1/cop2010sr1. pdf

2014. The World Factbook: Malaysia. Central Intelligence Agency. https://www.cia.gov/library/publications/theworld-factbook/geos/my.html

Brown, Michael E., and Sumit Ganguly. 2003. Fighting Words: Language Policy and Ethnic Relations in Asia. MIT Press.

Buøi Khaùnh Theá. 2003. Multilingual education in the community of minority peoples of Vietnam. National University, Ho Chi Minh City, Vietnam.

Castro, Nestor. 2011. The Socio-Cultural Situation in the Philippines, Opening Address for the International Conference on Social Environment in Contemporary East Asia in the Age of Globalization: International and Interdisciplinary Studies on Ageing, Agriculture and Multicultural Situations. Nagoya. February 21-22.

Chaedar Alwasilah. 2013. “Unlocking Indonesian language policy, “ Jakarta Post, June 15.

http://www.thejakartapost.com/news/2013/06/15/unlocking-indonesian-language-policy.html

Chua, Amy. 2003. "Minority rule, majority hate." Asia Times. June 7.

http://www.atimes.com/atimes/Front_Page/EF07Aa01.html

Eisenstadt, S.N., and Rokkan, Stein, eds. 1973. Building States and Nations: Analyses by Region. Beverly Hills: Sage Publications.

Espiritu, Clemencia. 2011. Language Policies in the Philippines. National Commission for Culture and the Arts. http://www.ncca.gov.ph/about-culture-and-arts/articles-on-c-n-a/article.php?igm=3\&i=217

Guan, Lee Hock, and Leo Suryadinata. 2007. Language, Nation and Development in Southeast Asia. Singapore: ISEAS Publishing.

Hartanto, Wendy. 2013. The 2010 Indonesia Population Census, United Nations Statistics Division.

http://unstats.un.org/unsd/censuskb20/Attachments/2009IDN_ISI-

GUIDfba441dd463e4ca5907f1a1ae508f3ff.pdf

Hing, Kam, and Tan Chee Beng, eds. 2000. The Chinese in Malaysia. Kuala Lumpur: Oxford University Press.

Ho, W. K. and R. Y. L. Wong, eds. 2000. Language Policies and Language Education: the Impact in East Asian Countries in the Next Decade, Singapore: Times Academic Press.

Hsiao, Shiching. 1998. History of Chinese-Philippine Relations. Quezon City: Bookman Printing House.

Khánh, Trần. 1993. The Ethnic Chinese and Economic Development in Vietnam, Singapore: Institute of Southeast Asian Studies.

Lee, Kam Hing. 2000. The Chinese in Malaysia. Kuala Lumpur: Oxford University Press.

Ling, Huping. 2008. Emerging Voices: Experiences of Underrepresented Asian Americans, Piscataway: Rutgers University Press.

Liu, Amy H., and Jacob I. Ricks. 2012. "Coalitions and Language Politics: Policy Shifts in Southeast Asia." World Politics. 64(3).

Lwin, Thein. 2011. "Languages, Identities, and Education - in Relation to Burma/Myanmar," Shan Herald Agency for News. October 15. http://www.shanland.org/images/docs/lwin-language-aritcle-english-15thoct11.pdf

McVey, Ruth. 1992. Southeast Asian Capitalists. Ithaca: Cornell University Press.

Murray, Douglas P. 2009. Chinese Education in South-East Asia. The China Quarterly. 20.

Palanca, Ellen H. 2002. "A comparative study of Chinese education in the Philippines and Malaysia." Asian Studies. 38(2).

Purdey, Jemma. 2006. Anti-Chinese Violence in Indonesia 1996-1999. Honolulu: University of Hawaii Press.

Rappa, Antonio L., and Lionel Wee. 2006. Language Policy and Modernity in Southeast Asia: Malaysia, the Philippines, Singapore, and Thailand. New York: Springer. 
Rieffel, Lex. 2010. Myanmar/Burma: inside challenges, outside interests. Washington: Brookings Institution Press.

Smalley, William A. 1994. Linguistic Diversity and National Unity: Language Ecology in Thailand. Chicago: University of Chicago Press.

Stuart-Fox, Martin. 2003. A Short History of China and Southeast Asia: Tribute, Trade and Influence. Crows Nest: Allen \& Unwin.

Suryadinata, Leo. 2008. Ethnic Chinese in Contemporary Indonesia, Singapore: Institute of Southeast Asian Studies.

Tort, Marvin A. 2013. Asia Weekly: Mandarin rises in the Philippines. China Daily. December 20. http://www.chinadailyasia.com/life/2013-12/20/content_15107475.html

Vandenbosch, Amry. 1947. The Chinese in Southeast Asia, The Journal of Politics. February 9(1).

Weightman, George H. 1960. The Philippine Chinese: A Cultural History of a Marginal Trading Company. Ann Arbor, Michigan: UMI Dissertation Information Service.

Weinstein, Brian, ed. 1990. Language Policy and Political Development. Norwood: Ablex Publishing, Norwood.

Williams, Jenny. 2004. The Chinese Exlusion Act 1882. The Web Chronology Project.

http://www.thenagain.info/WebChron/USA/ChineseExclusion.html

\section{ENDNOTES}

Multiculturalism refers to the peaceful integrative effects of cultural communities and multiracialism to peaceful co-existence of ethnic communities built along ethnic or racial lines. [Rappa, Antonio L., and Lionel Wee. 2006. Language Policy and Modernity in Southeast Asia: Malaysia, the Philippines, Singapore, and Thailand. New York: Springer.]

Political leaders have to decide first if a national language should be established. They have to weigh the advantages of having a national language (promotion of national unity) against the disadvantages (possible backlashed from ethno-linguistic minorities). Second, they have to determine how many and which languages should have this status. Third, they have to decide about functions national languages will play. Finally, they have to decide how national languages will be used (in the government, courts, media, schools, etc.). [Brown, Michael E., and Sumit Ganguly. 2003. Fighting Words: Language Policy and Ethnic Relations in Asia. MIT Press.]

Dialects are not forbidden, but also not encouraged by the Chinese government. The dialects have no written form (with a couple of exceptions such as Shanghainese and Cantonese).

There was a 2014 census conducted in Myanmar in March and April, but the final results will only be released in May 2015.

The word bahasa means language in Indonesian, Bahasa Indonesia thus means Indonesian Language.

The military government (1988-2010) classified 135 ethnic groups in Burma: 53 ethnic groups in Chin State, 12 in Kachin State, 11 in Karen State, 9 in Kayah State, 1 in Mon State, 7 in Rakhaing State, 33 in Shan State and 9 Burman ethnic groups. [Lwin, Thein. 2011. "Languages, Identities, and Education - in Relation to Burma/Myanmar," Shan Herald Agency for News. October 15.]

Taiwan is a major destination for Burmese Chinese, as the Taiwanese government offers aid and scholarship incentives to 'returning' overseas Chinese to study and settle there. Zhonghe District in Taipei is home to 40,000 Burmese Chinese. 
This policy reversal preceded the establishing of diplomatic relations with the People's Republic of China.

The basis for Filipino, the Philippine national language, is Tagalog, which had in the 1930s been spoken only in Manila and the surroundings. In the1970s more than half the Filipinos were regularly communicating in Tagalog. Filipino replaces many Tagalog words by English- and Spanish-derived words. For many Filipinos Tagalog is not their first language. They learn to speak Filipino in schools.

As embodied in the Department of Education, Culture, and Sports Order No. 25, Filipino shall be used as medium of instruction in social studies, music, arts, physical education, economics, practical arts and character education. English is allocated to science, mathematics and technology subjects.

Thailand had a traditional two-way classification of languages: Thai and foreign, with no attempt to distinguish between languages which may be widely spoken among the locals, such Chinese, and truly foreign languages. Although in1978 the National Education Council introduced a four-way classification (national language = Standard Thai, foreign languages, regional languages $=$ dialect of Standard Thai, minority languages) the two-way logic remains in place. [Noss, R. B., ed. 1984. An Overview of Language Issues in South-east Asia 1950-1 980. Singapore: Oxford University Press.]

Since 1949 overseas Chinese have been offered various enticements to return to their homeland. Several millions have done so. The biggest influx was in the end of the 1970s, when ethnic Chinese fled Vietnam as refugees and settled down in Southern China, mainly on Hainan Island. 